\title{
IMMUNOLOGICAL RESPONSES OF GUINEA-PIGS TO BERYLLIUM SALTS
}

\author{
J. VACHER* \\ M.R.C. Toxicology Unit, Woodmansterne Road, Carshalton, Surrey
}

Chronic pulmonary disease (Weber and Engelhardt, 1933) and contact dermatitis (DeNardi, Van Ordstrand and Carmody, 1949) have been observed in many beryllium workers. An immunological mechanism was first suggested (Sterner and Eisenbud, 1951) because only a small percentage of exposed workers developed chronic lesions, with an insidious onset several months after exposure. The histological picture of the granulomatous lesions was characteristic. Sterner and Eisenbud's hypothesis was supported by the fact that the cutaneous reactions to soluble beryllium salts of the delayed hypersensitivity type (Curtis, 1951) were seen in patients suffering from berylliosis, and granuloma formation in people who were cut by beryllium phosphor-coated glass from broken lamps (Dutra, 1951). Furthermore, beryllium fluoride is an excellent sensitiser in healthy man (Curtis; McCord, 1951).

Similar responses have been produced experimentally in animals. Chiappino, Cirla and Vigliani (1969) demonstrated that after endotracheal injection of beryllium oxide (BeO) a lung reaction characteristic of hypersensitivity developed in some guinea-pigs, and that these animals also had dermal hypersensitivity to soluble salts. Furthermore, the application of the sulphate $\left(\mathrm{BeSO}_{4}\right)$ to the ear induced the same histological changes in the regional lymph-node as known sensitisers. A state of delayed hypersensitivity has also been induced with various salts of beryllium given by different routes (Belman, 1957, 1969; Alekseeva, 1966; Polák, Barnes and Turk, 1968; Chiappino et al., 1969). These findings suggest that the tissue reactions induced by beryllium are immunological ones of the delayed hypersensitivity type. This was confirmed in guinea-pigs by passive transfer by means of lymphoid cells (Cirla, Barbiano di Belgiojoso and Chiappino, 1968), and by the inhibition of the intradermal reaction to beryllium by antilymphocytic serum (Chiappino, Barbiano di Belgiojoso and Cirla, 1968).

The work reported here shows that immunological paralysis (or tolerance) to beryllium can be readily induced in adult guinea-pigs, and can be recognised by inhibition of the delayed skin-hypersensitivity reactions to the topical application of beryllium in pre-treated animals. Beryllium compounds may induce either sensitisation or tolerance. Beryllium as the citrate is tolerogenic, whereas a compound more easily phagocytosed or one that reacts with proteins is immunogenic. This supports the conclusions previously drawn by Macher and Chase (1969a) from the results of their work on the elimination from the skin of

Received 9 Mar. 1971; accepted 24 Aug. 1971. France.

J. MED. MICROBIOL.-VOL. 5 (1972) 
various sensitisers (dinitrochlorobenzene and picryl chloride) injected intradermally. It is also shown that the tolerant state induced by beryllium can fit the model described by Mitchison $(1964,1968)$ for protein antigen.

\section{MATERIALS AND METHODS}

Animals. Male guinea-pigs of the Dunkin Hartley (Porton) strain from M. Mitchard, Dewbrook, Vines Cross Road, Horam, Sussex (source 1), and A. Tuck \& Son Ltd, Laboratory Animal Breeding Station, Rayleigh, Essex (source 2) were used. The guinea-pigs weighed $577 \pm 13 \mathrm{~g}$ (SE for $\mathrm{n}=94$ ), except in the comparison of the responses in the animals from the two sources, when smaller ones were used (table I); they were fed on diet S.G.1 (Short and Gammage, 1959) with $1.5 \mathrm{~kg}$ of added vitamin $\mathrm{C}$ per ton.

Preparations of beryllium used. $\mathrm{BeF}_{2}$ (stock solution 20 per cent. in water) and $\mathrm{BeSO}_{4}$. $4 \mathrm{H}_{2} \mathrm{O}$ were dissolved in de-ionised water or in MCWT (methyl-cellosolve : water : Tween “ 80 ":: $45: 45: 10$ ). $1.064 \mathrm{~mm}-\mathrm{BeSO}_{4}$ (aqueous solution) was incorporated in an equal volume of complete Freund adjuvant (Difco). Be phosphate was prepared by mixing $\mathrm{M}-\mathrm{BeSO}_{4}$, and $3 \mathrm{M}-\mathrm{Na}_{2} \mathrm{HPO}_{4}$; the $p \mathrm{H}$ of the final suspension was adjusted with $\mathrm{NaOH}$ until a slight turbidity appeared $(p \mathrm{H}$ approximately $7 \cdot 4)$. Be citrate was prepared by mixing equimolar solutions (unless otherwise indicated) of $\mathrm{BeSO}_{4} .4 \mathrm{H}_{2} \mathrm{O}$ and trisodium citrate. Some solutions were made radioactive by addition of carrier-free ${ }^{7} \mathrm{BeCl}_{2}$ (Radiochemical Centre, Amersham, Bucks.).

Administration of the beryllium solutions. Except for percutaneous application when $\mathrm{BeF}_{2}$ and $\mathrm{BeSO}_{4} \cdot 4 \mathrm{H}_{2} \mathrm{O}$ were used dissolved in $\mathrm{MCWT}$, beryllium salts were injected as an aqueous solution of different concentrations in the following volumes: $0 \cdot 1 \mathrm{ml}$ intradermally (under ether anaesthesia, with $0.5-\mathrm{ml}$ syringes sealed with warmed wax to avoid any leakage); $4 \mathrm{ml}$ per $\mathrm{kg}$ intraperitoneally and $1 \mathrm{ml}$ per $\mathrm{kg}$ intravenously (through the penis vein, under ether anaesthesia).

Skin test for the determination of sensitivity. The hair on the back was removed with electric clippers the day before the application of $0.03 \mathrm{ml}$ of $0.02,0.1$ or $0.4 \mathrm{M}^{-B^{2}} \mathrm{~F}_{2}$ solution with MCWT per $\mathrm{cm}^{2}$. The solutions were spread in the direction of the hair growth and allowed to dry, sometimes assisted by an electric hair-drier. The skin reactions were examined after $48 \mathrm{hr}$ and scored as follows: (0) no reaction or doubtful; (1) mild but appreciable reactions; (2) obvious definite redness; (3) strong reaction; (4) very strong reaction with oedema of the skin and some haemorrhagic spots. The results are expressed as the number of animals in each group that responded and as the mean score of all the animals in a group. The maximum theoretical score that any animal could contribute was 12 .

Sensitisation. For sensitisation, skin tests as described above were repeated at 7-day intervals for 2-4 wk. The results are expressed as previously and also as the mean score for a series of skin tests. Attempts were also made to sensitise the animals by intradermal, intraperitoneal or intravenous injections. In some experiments after intradermal injection, the injection sites were removed $2 \mathrm{hr}$ later by excising them under ether anaesthesia.

Statistical examinations were done by analysis of variance, with a two-way classification to allow comparison of different groups of animals versus the different repeated skin tests. Where there was no statistical difference within the repeated skin tests, the results were pooled and analysis repeated by the previous method. When the ratio (F) was significant, the means were compared by Duncan's multiple Range Test (Duncan, 1955) or Least Significant Difference; the level of significance was taken as $P \leqq 0 \cdot 01$.

Elimination of beryllium from the skin. Radioactive solutions of Be fluoride, sulphate and citrate were injected intradermally in a volume of $0.1 \mathrm{ml}$ into the skin of the back under ether anaesthesia. Two or twenty hours later, the animals were killed and the injection sites excised. The radioactivity due to ${ }^{7} \mathrm{Be}$ was measured with a Packard Autogamma Scintillation Counter. The results are expressed as the percentages of radioactivity remaining in the skin. 


\section{RESULTS}

\section{Sensitisation of guinea-pigs by beryllium compounds}

Different factors were investigated, the results of which are partly summarised in table I.

Salts of beryllium. Fluoride and sulphate given to guinea-pigs from source 1 showed that $\mathrm{BeF}_{2}$ was a much more potent sensitiser than $\mathrm{BeSO}_{4}$ as demonstrated by the greater number ( 60 per cent.) of animals sensitised after three applications compared with 30 per cent. for sulphate, and by the rapidity of the

\section{TABLE I}

Skin sensitisation of male guinea-pigs by topical application of beryllium salts

\begin{tabular}{|c|c|c|c|c|c|c|}
\hline \multirow{2}{*}{$\begin{array}{l}\text { Guinea-pigs } \\
\text { from } \\
\text { source }\end{array}$} & \multirow{2}{*}{$\begin{array}{l}\text { Mean weight } \\
\pm \mathrm{SE}(\mathrm{g})\end{array}$} & \multirow{2}{*}{$\begin{array}{c}\text { Sensitiser } \\
\text { used }\end{array}$} & \multicolumn{4}{|c|}{$\begin{array}{l}\text { Number of animals giving positive responses/number } \\
\text { tested, and (below and to right) mean score in skin } \\
\text { test* no. }\end{array}$} \\
\hline & & & 1 & 2 & 3 & 4 \\
\hline 1 & $387 \pm 3$ & $\begin{array}{l}\mathrm{BeSO}_{4} \\
\mathrm{BeF}_{2}\end{array}$ & $\begin{array}{ll}2 / 10 & \\
& 0.2 \\
7 / 10 & \\
& 1 \cdot 0\end{array}$ & $\begin{array}{cc}2 / 10 & \\
& 0 \cdot 56 \\
6 / 10 & \\
& 2 \cdot 1\end{array}$ & $\begin{array}{cc}3 / 10 & \\
& 1 \cdot 44 \\
6 / 10 & \\
& 2 \cdot 9\end{array}$ & $\begin{array}{l}\cdots \\
\cdots\end{array}$ \\
\hline 2 & $371 \pm 12 \cdot 5$ & $\begin{array}{l}\mathrm{BeF}_{2} \\
\mathrm{BeF}_{2}\end{array}$ & $\begin{array}{ll}5 / 8 & \\
& 1.37 \\
9 / 14 & \\
& 0.93\end{array}$ & $\begin{array}{ll}8 / 8 & \\
9 / 14 & 5 \cdot 0 \\
& 2 \cdot 29\end{array}$ & $\begin{array}{ll}8 / 8 & \\
7 / 14 & 6 \cdot 25 \\
& 2 \cdot 77\end{array}$ & $\begin{array}{l}\cdots \\
\cdots\end{array}$ \\
\hline 1 & $378 \pm 3$ & $\mathrm{BeF}_{2} \ddagger$ & $\begin{array}{ll}0 / 4 & \\
& 0\end{array}$ & $\begin{array}{ll}2 / 4 & 1.5\end{array}$ & $\begin{array}{ll}1 / 4 & \\
& 1.5\end{array}$ & $\cdots$ \\
\hline 2 & $\begin{array}{l}\text { Standard } \\
\text { controls } \dagger\end{array}$ & $\mathrm{BeF}_{2}$ & ${ }_{0.83}^{11 / 23}$ & ${ }_{4 \cdot 35}^{21 / 23}$ & $18 / 18_{5 \cdot 0}$ & ${ }^{22 / 23} 4 \cdot 61$ \\
\hline
\end{tabular}

* $140 \mu \mathrm{g}$ beryllium applied to the skin at each skin test.

$\dagger$ Pooled controls used in the various other experiments of the present study.

$¥$ Groups of guinea-pigs pre-treated by injection of $5 \mu \mathrm{g}$ beryllium (as fluoride) per $\mathrm{kg}, 25$ and 18 days before the first skin test.

development as well as the intensity of the sensitisation. Some non-specific skin reactions were also observed after the first application of Be fluoride.

Source of guinea-pigs. Guinea-pigs of the same strain supplied by two breeders were not equally susceptible to the percutaneous application of $\mathrm{BeF}_{2}$. Analysis of variance showed that greater numbers of animals from source 2 (100 as against 60 per cent.) were sensitised and the reactivity was more pronounced than in those from source 1. Guinea-pigs from source 2 were used in further experiments.

Reproducibility. Analysis of variance showed that groups of animals from source 2 did not differ in their reactivity to beryllium, so that they were pooled 
(table I, " Standard controls ") for comparison in some experiments run without their own controls.

Comparison between the different skin tests showed that only the cutaneous reactions following the first application of beryllium differed significantly from those observed during subsequent applications. These were, in fact, non-specific inflammatory reactions; the mean score for a series of skin tests was therefore determined for the period of active sensitisation itself, and the first skin test was excluded.

Influence of the route of administration. The dose of beryllium administered by topical application of $\mathrm{BeF}_{2}$ for each skin test was $140 \mu \mathrm{g}$ (i.e., $350 \mu \mathrm{g} \mathrm{Be}$ per $\mathrm{kg}$ ), part of which remained on the surface of the skin. Attempts to elicit skin sensitisation were also made by injecting solutions of beryllium compounds. Sensitisation was judged 15 days later by skin testing with $\mathrm{BeF}_{2}$ in MCWT and by active sensitisation elicited by subsequent repeated skin paintings.

(1) Intradermal (ID) injection (table VII, groups 2, 3, 5). Analysis of variance on the intensity of the skin reactions did not demonstrate any difference between the various groups given injections of different salts of beryllium. However, on the basis of the number of animals that reacted to beryllium during the first and second skin test, there was some indication that fluoride and sulphate were better sensitisers than citrate.

In a comparison between animals in which beryllium was first administered either percutaneously or intradermally (table VII, group 1 versus groups $2,3,5$ ), it appeared that the percutaneous route was much more efficient in producing sensitisation. However, the dose given percutaneously was much greater and the least amount of beryllium that would produce sensitisation is unknown.

(2) Intravenous (IV) injection. Injection of beryllium (19.15 $\mu \mathrm{g} \mathrm{per} \mathrm{kg}$ ) by the IV route had no sensitising effect as shown by skin testing 15 days later, and did not modify significantly further active sensitisation (see table IV, fluoride; table VII, group 8, citrate).

(3) Intraperitoneal (IP) injection. A dose of $5 \mu \mathrm{g}$ Be per $\mathrm{kg}$ given 25 and 18 days before skin testing reduced the non-specific reactions observed after the first skin test and decreased the active sensitisation elicited by repeated skin paintings. This partial immunological paralysis was demonstrated (standard controls, table I) by the fact that only 25 per cent. of the animals were sensitised after three topical applications of $\mathrm{BeF}_{2}$ compared with 50 per cent. of untreated guinea-pigs, and there was a reduction in the intensity of the skin reactions.

\section{Immunological paralysis induced in adult guinea-pigs}

The treatment needed to induce tolerance was investigated in more detail. Guinea-pigs from source 2 were given an intraperitoneal injection of various beryllium compounds 7 or 15 days or on both days before their immunological state was checked by skin testing with $\mathrm{BeF}_{2}$. Active sensitisation was performed by repeated applications for 2-4 weeks and comparisons made with untreated controls. Doses of beryllium compounds are expressed in $\mu \mathrm{g} \mathrm{Be}$ per $\mathrm{kg}$. Different factors were investigated, and the results are given in tables II-V. 
Influence of the dose (table II). The degree of immunological paralysis judged by the number of animals responding and by the intensity of the sensi-

TABLE $\amalg$

Effect of previous intraperitoneal injection of $\mathrm{BeF}_{2}$ on the sensitisation of male guinea-pigs by percutaneous application of $\mathrm{BeF}_{2}$ in $\mathrm{MCWT}$

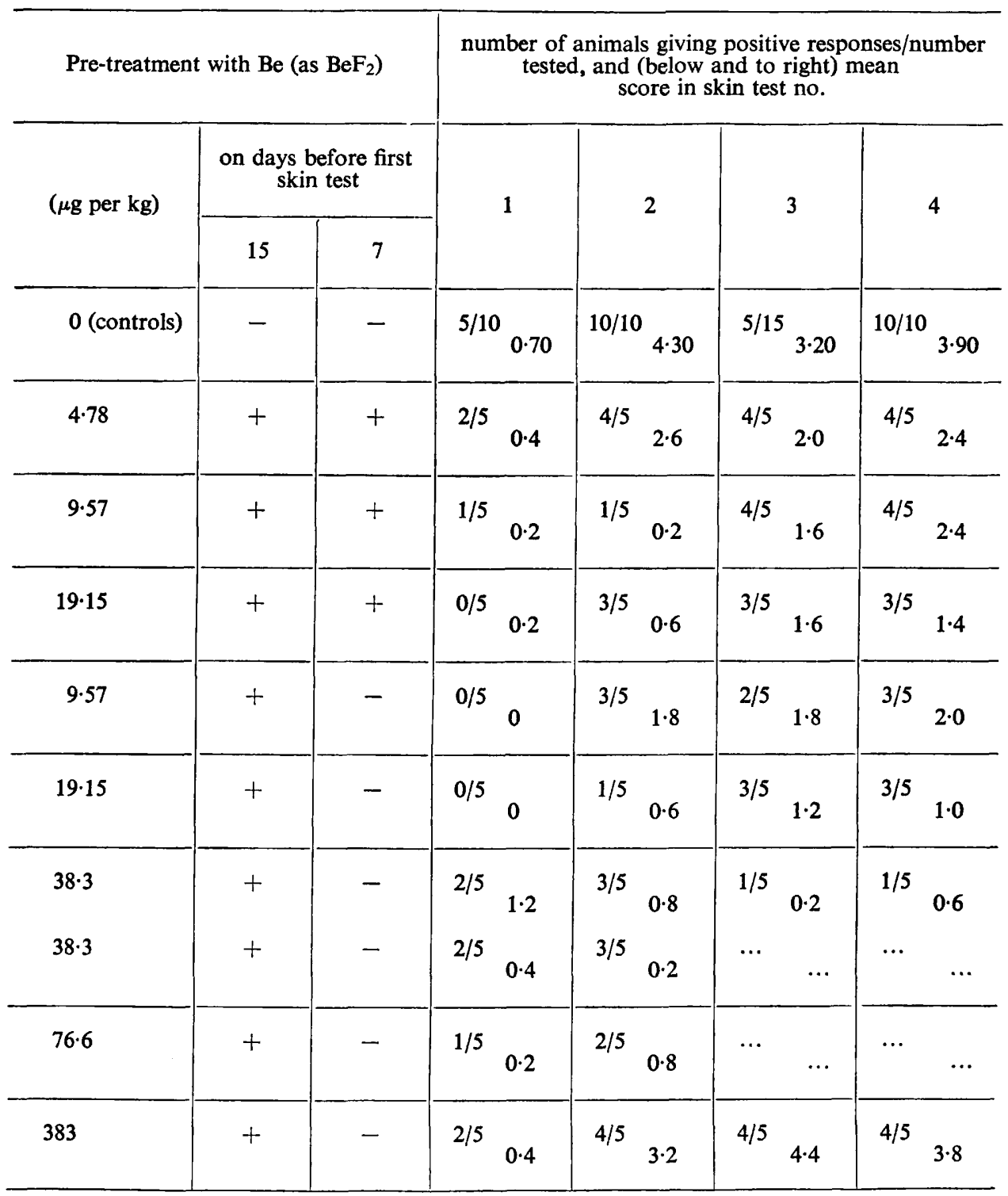

tisation obtained after further repeated skin paintings, was determined in guinea-pigs that had been given an injection of $\mathrm{BeF}_{2}$ intraperitoneallv. 


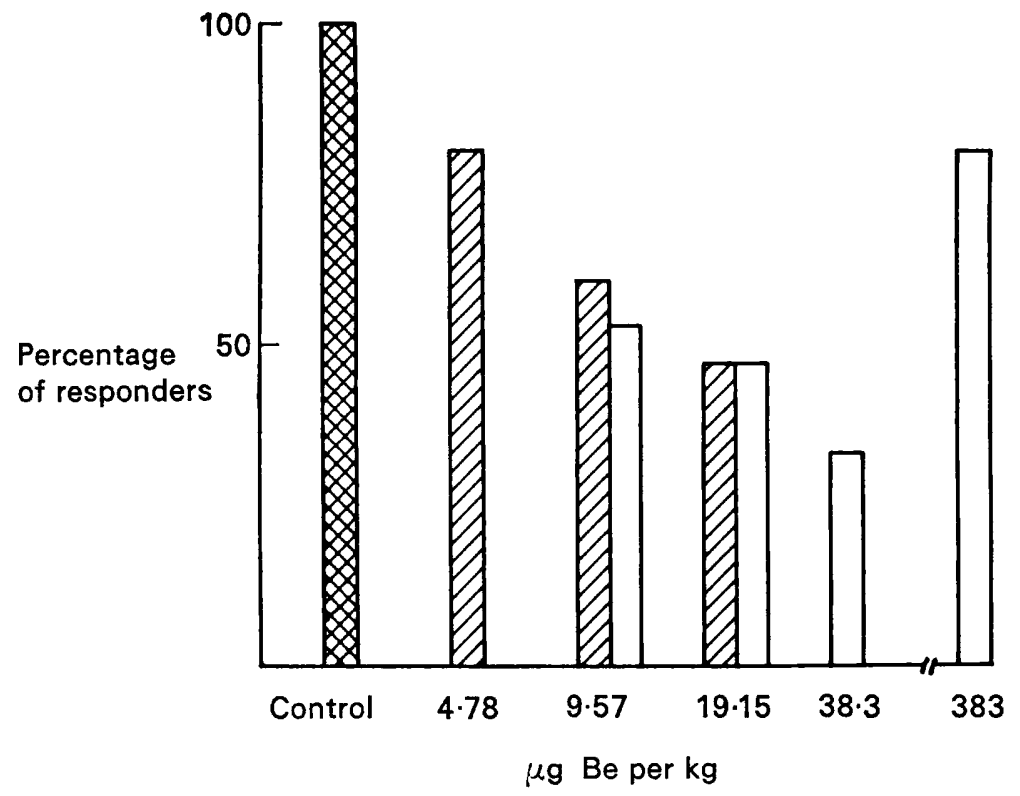

FIG. 1a.-Percentage of responders derived from two series of skin tests, excluding the first skin test of each series so as to exclude non-specific responses.

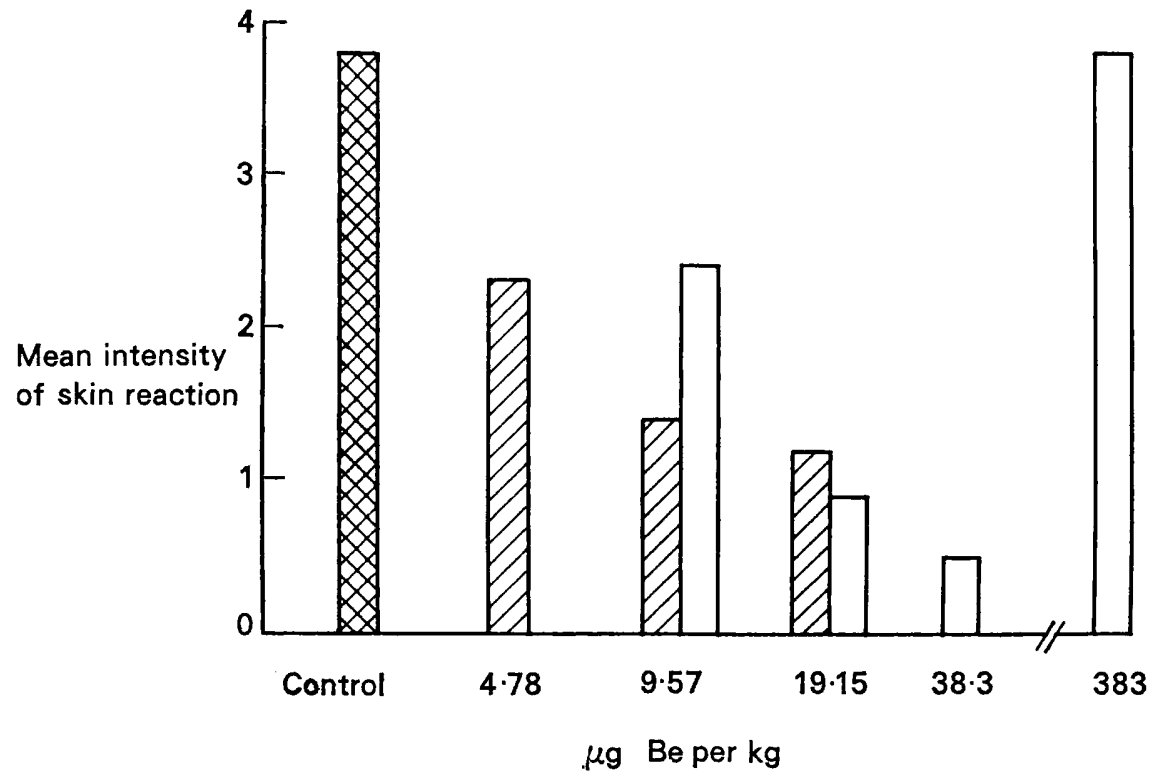

Fig. 1b.-Mean scores for the intensity of the skin reactions in two series of skin tests, excluding the first skin test of each series so as to exclude non-specific responses.

FIG. 1.-Immune paralysis induced in male guinea-pigs by pre-treatment with various doses of $\mathrm{BeF}_{2}$ IP. $\otimes$ No pre-treatment. Pre-treatment at -15 and -7 days. $\square$ One pre-treatment at -15 days. 
The response of the pre-treated animals differed significantly from the controls except in those given the highest dose (383 $\mu \mathrm{g} \mathrm{Be}$ per $\mathrm{kg})$.

Although no difference can be demonstrated at the 1 per cent. level between the groups pre-treated with various doses of beryllium, there was an indication that the degree of immune tolerance was approximately proportional to dose in the range $4 \cdot 78-38 \cdot 3 \mu \mathrm{g}$ per $\mathrm{kg}$ (fig. $1 a$ and $b$ ). At high doses no immune paralysis was produced.

Duration of immunological paralysis. This was studied by repeating the skin tests at 7-day intervals for 76 days after the injection of beryllium. The duration of the tolerant state is, to a certain extent, also dose-related, as is illustrated by the number of animals that remained non-responders in comparison with those not pre-treated with beryllium. Thus, of guinea-pigs given 9.57, 19.15 and $38.3 \mu \mathrm{g}$ Be per $\mathrm{kg}, 20,40$, and 60 per cent. respectively were still non-responders after 76 days (table III).

TABLE III

Duration of immunological paralysis induced by pre-treatment with a range of doses of $\mathrm{BeF}_{2}$ injected IP before the first percutaneous skin test with $\mathrm{BeF}_{2}$

\begin{tabular}{|c|c|c|c|c|c|c|c|c|}
\hline \multicolumn{3}{|c|}{ Pre-treatment with $\mathrm{Be}$ as $\mathrm{BeF}_{2}$} & \multicolumn{6}{|c|}{$\begin{array}{l}\text { Number of animals giving positive response/number } \\
\text { tested, in skin tests on day after first pre-treatment } \\
\text { injection }\end{array}$} \\
\hline \multirow{2}{*}{$\mu \mathrm{g}$ per $\mathrm{kg}$} & \multicolumn{2}{|c|}{$\begin{array}{l}\text { on days before 1st } \\
\text { skin test }\end{array}$} & \multirow{2}{*}{15} & \multirow{2}{*}{22} & \multirow{2}{*}{29} & \multirow{2}{*}{36} & \multirow{2}{*}{56} & \multirow{2}{*}{76} \\
\hline & 15 & 7 & & & & & & \\
\hline $\begin{array}{l}0 \text { (controls) } \\
4 \cdot 78 \\
9 \cdot 57 \\
19 \cdot 15 \\
9 \cdot 57 \\
19 \cdot 15 \\
38 \cdot 3\end{array}$ & $\begin{array}{l}- \\
+ \\
+ \\
+ \\
+ \\
+ \\
+\end{array}$ & $\begin{array}{l}- \\
+ \\
+ \\
+ \\
- \\
-\end{array}$ & $\begin{array}{l}5 / 10 \\
2 / 5 \\
1 / 5 \\
1 / 5 \\
0 / 5 \\
0 / 5 \\
2 / 5\end{array}$ & $\begin{array}{l}10 / 10 \\
1 / 5 \\
4 / 5 \\
1 / 5 \\
3 / 5 \\
1 / 5 \\
3 / 5\end{array}$ & $\begin{array}{l}5 / 5 \\
4 / 5 \\
4 / 5 \\
3 / 5 \\
2 / 5 \\
3 / 5 \\
1 / 5\end{array}$ & $\begin{array}{c}10 / 10 \\
4 / 5 \\
4 / 5 \\
3 / 5 \\
3 / 5 \\
3 / 5 \\
1 / 5\end{array}$ & $\begin{array}{c}10 / 10 \\
4 / 5 \\
5 / 5 \\
\dddot{4} \\
4 / 5 \\
3 / 5 \\
1 / 5\end{array}$ & $\begin{array}{c}10 / 10 \\
4 / 5 \\
5 / 5 \\
\dddot{4} \\
3 / 5 \\
3 / 5 \\
2 / 5\end{array}$ \\
\hline
\end{tabular}

Influence of beryllium compounds (table IV). The next question to answer was whether other beryllium salts could induce tolerance. Beryllium citrate, which remains in solution at physiological $p \mathrm{H}$, and beryllium phosphate, an insoluble compound, were injected IP in a single pre-treatment at -15 days, and the degree of tolerance compared on day 0 with that of uninjected controls and with that of guinea-pigs pre-treated with the same tolerogenic dose $(19 \cdot 15 \mu \mathrm{g}$ Be per $\mathrm{kg}$ ) of fluoride. Statistical examination shows that at the 1 per cent. level, fluoride and citrate induced a significant degree of tolerance, whereas phosphate did not.

Influence of the immunological state of the guinea-pigs. $\mathrm{BeF}_{2}$ injected IP in immunologically virgin animals induced a dose-related tolerance in a low doserange (table II); the same doses injected into guinea-pigs already sensitised by 


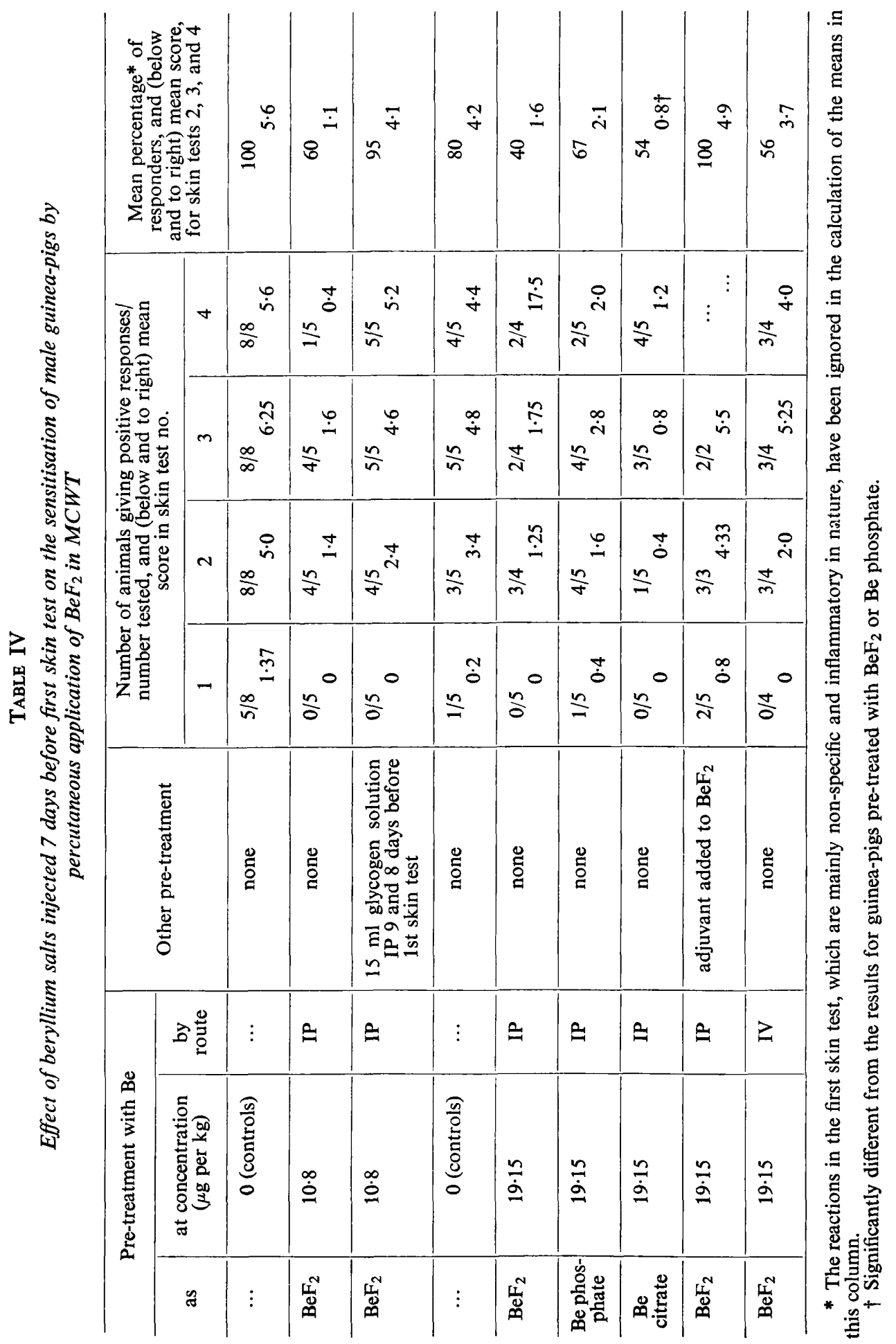


skin tests did not modify their immunological state, i.e., did not desensitise the animals (unpublished observations). However, bigger doses (400 $\mu \mathrm{g}$ per $\mathrm{kg}$ ) injected intravenously in the form of sulphate gave a transient desensitisation 7 days later, thus confirming the findings of Polák and Turk (1968), who used beryllium lactate.

Influence of the route of administration. The induction of immune tolerance by pre-treatment with beryllium can be induced by IP injection only, for the same dose given ID (table VII) or IV (tables IV and VII) does not modify the immunological status significantly, except perhaps when beryllium citrate is used (group 8, table VII).

Other experimental conditions modifying the induction of tolerance. The differences observed in the induction of tolerance by various beryllium compounds suggested a possible role played by their particle size. Citrate seems to be the most tolerogenic salt. To test the effect of phagocytosis by the reticuloendothelial (RE) system, a tolerogenic dose of $\mathrm{BeF}_{2}(19 \cdot 15 \mu \mathrm{g}$ Be per $\mathrm{kg}$ ) was injected IP in animals in which the RES activity was stimulated by incorporating $\mathrm{BeF}_{2}$ in complete Freund adjuvant (table IV). Comparison of skin reactions in these animals with those in animals given the same dose of beryllium in water showed a significantly greater degree of sensitisation, similar to that seen in untreated controls given repeated skin paintings.

The tolerogenic activity of beryllium $(10.8 \mu \mathrm{g}$ per $\mathrm{kg})$ was also found to be abolished by pre-treatment of the guinea-pigs with a solution of glycogen IP, which is known to stimulate macrophage proliferation (table IV).

\section{Other results}

As shown previously, beryllium can induce either skin sensitisation or immune tolerance depending on the route of administration and perhaps on the nature of the salts.

Therefore, the question arises to what extent these two phenomena take place during sensitisation by skin painting. This could be the result of a concomitant immunisation and tolerance, the former being predominant.

More detailed investigations were also done on the fate of injected beryllium into the skin in order to know more about its binding by skin proteins.

Elimination from the skin of labelled beryllium injected intradermally (ID). Solutions of beryllium compounds were made radioactive by addition of ${ }^{7} \mathrm{Be}$, and $0.1 \mathrm{ml}$ of various concentrations was injected ID into immunologically virgin guinea-pigs. The skin was removed 2 and $20 \mathrm{hr}$ later and the residual radioactivity measured. Table $\mathrm{V}$ shows that the elimination from skin was biphasic; within $2 \mathrm{hr}$ quite a large amount of beryllium disappeared, and then the elimination continued slowly over the next $18 \mathrm{hr}$. This disappearance was much more striking for beryllium citrate at the higher concentration.

The influence of concentration was studied in more detail with beryllium citrate. The results (fig. 2) showed that the percentage residual radioactivity in the skin $2 \mathrm{hr}$ after ID injection was inversely proportional to the molarity of beryllium from 0.001 to $0.05 \mathrm{M}$; then the rate of elimination became constant 
TABLE V

Elimination of ${ }^{7} \mathrm{Be}$-labelled compounds and carrier-free ${ }^{7} \mathrm{BeCl}_{2}$ from the intradermal injection sites

\begin{tabular}{|c|c|c|c|}
\hline \multirow{2}{*}{$\begin{array}{l}\text { Compound } \\
\text { injected* }\end{array}$} & \multirow{2}{*}{$\begin{array}{l}\text { Concentration } \\
\text { (M) }\end{array}$} & \multicolumn{2}{|c|}{$\begin{array}{l}\text { Mean percentage } \pm \text { SE of initial radio- } \\
\text { activity remaining in skin site } \neq \text { at time } \\
\text { after injection (hr) }\end{array}$} \\
\hline & & 2 & 20 \\
\hline $\mathrm{BeF}_{2}$ & $\begin{array}{l}0.01 \\
0.001\end{array}$ & $\begin{array}{l}74 \cdot 7 \pm 2 \cdot 40(11 \dagger) \\
69 \cdot 2 \pm 2 \cdot 56(6)\end{array}$ & $\begin{array}{l}72 \cdot 8 \pm 2 \cdot 39(7) \\
58 \cdot 5 \pm 1.85(6)\end{array}$ \\
\hline $\mathrm{BeSO}_{4}$ & $\begin{array}{l}0.01 \\
0.001\end{array}$ & $\begin{array}{l}78 \cdot 0 \pm 3 \cdot 46(6) \\
73 \cdot 4 \pm 4 \cdot 82(5)\end{array}$ & $\begin{array}{l}79 \cdot 0 \pm 4.49(7) \\
60 \cdot 8 \pm 4.06(6)\end{array}$ \\
\hline Be-citrate & $\begin{array}{l}0.01 \\
0.001\end{array}$ & $\begin{array}{l}36 \cdot 3 \pm 0.85(6) \S \\
58 \cdot 8 \pm 2 \cdot 93(6) \|\end{array}$ & $\begin{array}{l}28 \cdot 8 \pm 1 \cdot 51(7) \S \\
49 \cdot 2 \pm 1 \cdot 85(7) \S\end{array}$ \\
\hline $\begin{array}{l}{ }^{7} \mathrm{BeCl}_{2} \\
\text { (carrier-free) }\end{array}$ & 0.01 & $12 \cdot 4 \pm 2 \cdot 36(6)$ & $8 \cdot 9 \pm 1.27(5)$ \\
\hline
\end{tabular}

* In a volume of $0 \cdot 1 \mathrm{ml}$.

+ Numbers of animals in brackets.

No radioactivity was found in skin outside the injection sites.

These figures are less than those for $\mathrm{BeSO}_{4}$ or $\mathrm{BeF}_{2}(\mathrm{P}<0 \cdot 001)$.

I| These figures are less than those for $\mathrm{BeSO}_{4}$ or $\mathrm{BeF}_{2}(0.01<\mathrm{P}<0.02)$.

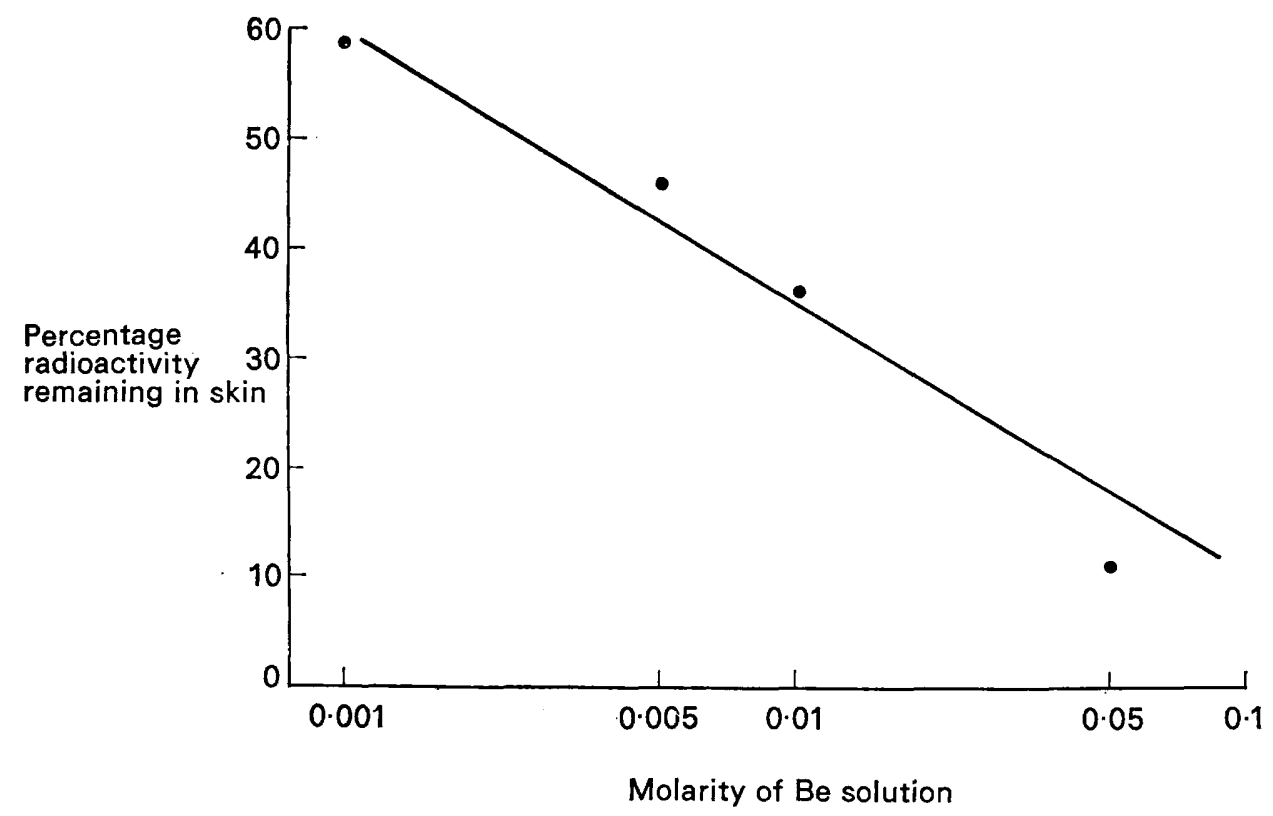

FIG. 2.-Elimination of $7 \mathrm{Be}$ citrate $(0 \cdot 1 \mathrm{ml})$ of various concentrations from the intradermal injection site. Results expressed as the percentage of initial radioactivity remaining in the skin $2 \mathrm{hr}$ after injection. 
at a maximum level since 90 per cent. disappeared within the first $2 \mathrm{hr}$. Any variation in the rate of elimination dependent on the site of injection was checked by injecting $0.01 \mathrm{M}-\mathrm{BeF}_{2}$ into various parts of the skin of the back on one animal. The mean score for six well-separated spots $(76 \pm 2.75$ per cent.) did not differ from that obtained in other experiments done in individual guinea-pigs (74.4 $\pm 2 \cdot 40$ per cent.). The rate of elimination probably depends on the binding of beryllium by the skin constituents. It has been shown that

TABLE VI

Mean percentage radioactivity $( \pm S E)$ remaining in the skin $2 \mathrm{hr}$ after ID injection of ${ }^{7}$ Be-labelled beryllium salts in guinea-pigs in different physical states

\begin{tabular}{|c|c|c|c|c|}
\hline \multirow{3}{*}{$\begin{array}{l}\text { Immunological state } \\
\text { of guinea-pigs }\end{array}$} & \multicolumn{4}{|c|}{ 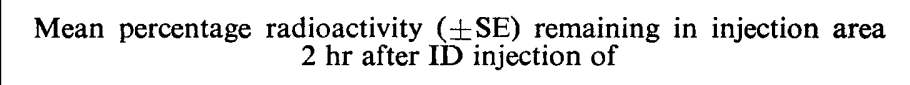 } \\
\hline & \multicolumn{2}{|c|}{ Be citrate at concentration (M) } & \multicolumn{2}{|c|}{$\mathrm{BeF}_{2}$ at concentration $(\mathrm{M})$} \\
\hline & 0.01 & 0.001 & $0 \cdot 01$ & $0 \cdot 001$ \\
\hline “Virgin" $(\mathrm{V})$ & $36 \cdot 3 \pm 0 \cdot 85(6)^{*}$ & $58 \cdot 8 \pm 2.93(6) \dagger$ & $74 \cdot 7 \pm 2 \cdot 40(11)$ & $69 \cdot 2 \pm 2 \cdot 56(6) \S$ \\
\hline Sensitised (S) & $44 \cdot 6 \pm 1 \cdot 15(7)$ & $48 \cdot 7 \pm 3 \cdot 75(8) \S \rrbracket$ & $74 \cdot 8 \pm 2 \cdot 11(6)$ & $76 \cdot 0 \pm 2 \cdot 78(7) \S$ \\
\hline $\begin{array}{l}\text { Given } 19 \cdot 15 \mu \mathrm{g} \mathrm{Be} \text { per } \mathrm{kg} \text { IP } 2 \text { days } \\
\text { before expt (I) }\end{array}$ & $41 \cdot 0 \pm 1 \cdot 53^{* *}$ & $47 \cdot 2 \pm 2 \cdot 78 \ddagger \dagger \dagger$ & $76 \cdot 4 \pm 2 \cdot 12$ & $\cdots$ \\
\hline $\begin{array}{l}\text { Immunologically paralysed by } \\
\text { injection of } 19 \cdot 15 \mu \mathrm{g} \mathrm{Be} \mathrm{per} \\
\text { kg IP } 15 \text { days before expt (P) }\end{array}$ & $44 \cdot 5 \pm 4 \cdot 50(8)$ & $41 \cdot 4 \pm 3 \cdot 51(8)$ & $\cdots$ & $77 \cdot 1 \pm 5 \cdot 72(5)$ \\
\hline
\end{tabular}

* Number of guinea-pigs used in brackets.

+ Significantly greater $(\mathrm{P}<0.001)$ than figure at $0.01 \mathrm{M}$.

$\ddagger$ Significantly greater $(0.02<\mathrm{P}<0.05)$ than figure at $0.01 \mathrm{M}$.

$\S$ Not significantly different from figure at $0.01 \mathrm{M}$.

II In comparison with $\mathrm{S}, \mathrm{V}$ figure is significantly less $(\mathrm{P}<0 \cdot 001)$.

In comparison with $\mathrm{S}, \mathrm{V}$ figure is significantly greater $(0.02<\mathrm{P}<0.05)$

** In comparison with I, V figure is significantly less $(P<0.001)$.

t† In comparison with I, V figure is significantly greater $(0.001<\mathbf{P}<0.01)$.

non-specific skin reactions are observed during the first skin test (table I), and that they are suppressed by the previous injection of a tolerogenic dose of beryllium (table II). Therefore, the question arises whether prior contact with beryllium modifies the binding to skin of beryllium given later. The elimination from the skin was therefore studied in animals already sensitised by skin painting, animals made tolerant with $\mathrm{BeF}_{2}$ given IP, and animals given an IP injection of the same tolerogenic dose of beryllium $(19 \cdot 15 \mu \mathrm{g}$ per $\mathrm{kg})$, but 2 days earlier (table VI). The rates of elimination of two different molar concentrations of $\mathrm{BeF}_{2}(0.01$ and $0.001 \mathrm{M})$ in the various groups were identical with that found in immunologically virgin animals. 


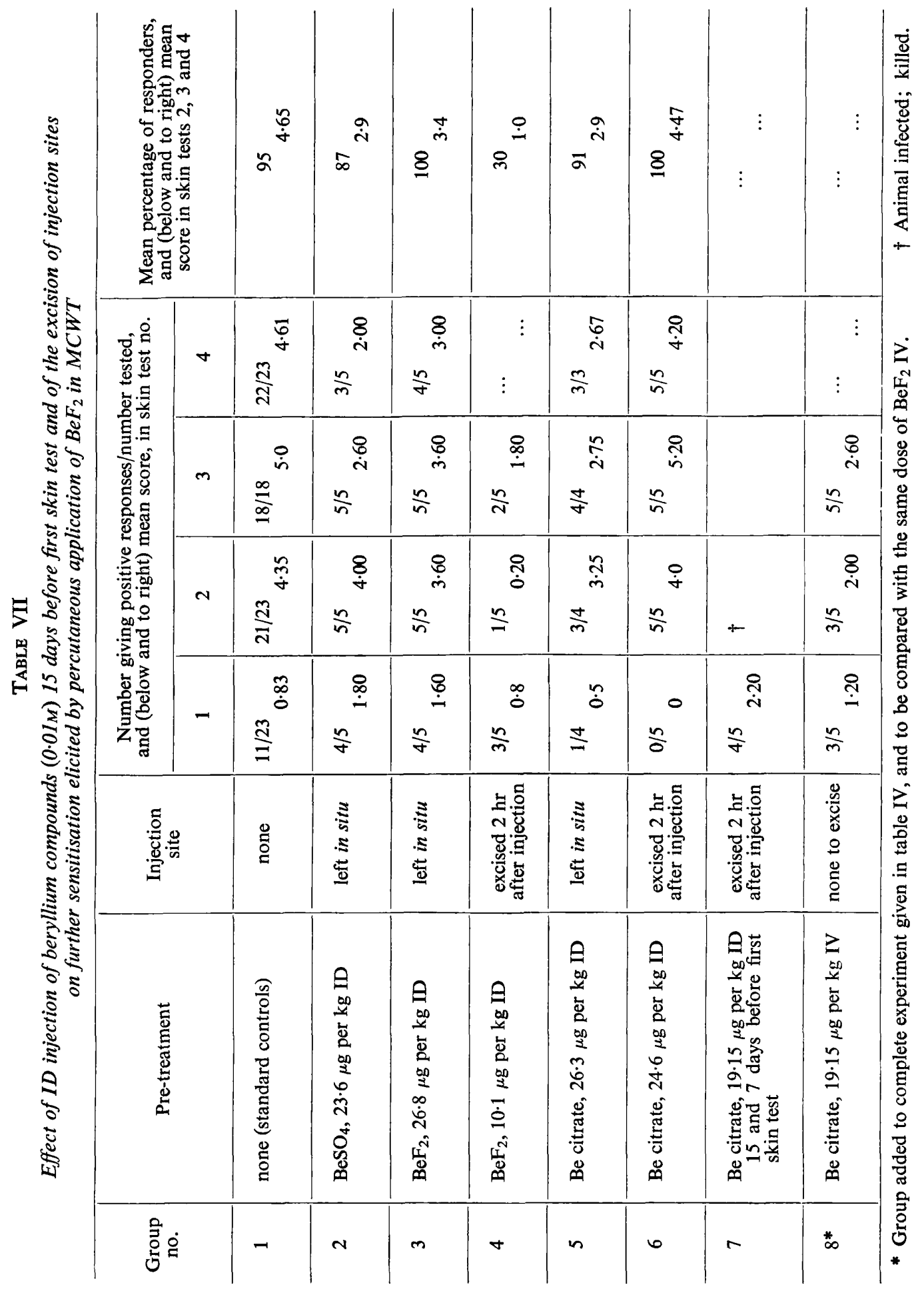


After beryllium citrate the elimination rate was fairly constant in the various groups that had received beryllium previously, either percutaneously (sensitised group) or parenterally (tolerant and injected groups). In these animals, therefore, unlike the findings in virgin animals, no statistical difference was noticed between the two concentrations used.

Influence of excision of the sensitising injection sites. After an ID injection of beryllium, one part escapes very quickly, the other remains in situ; the imunological role played by these two parts of beryllium was examined. Guinea-pigs
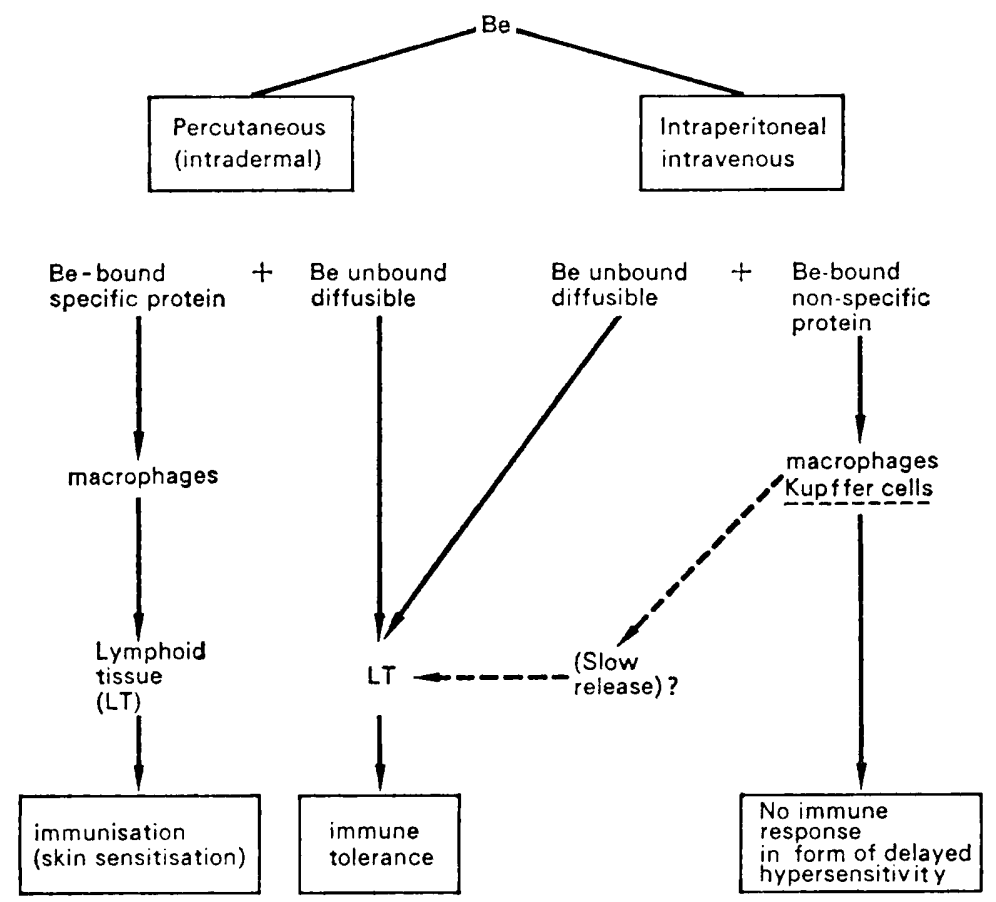

FIG. 3.-Factors affecting the immunological response to beryllium salts, and a suggestion on the methods by which they do so.

were given an intradermal injection of $0.1 \mathrm{ml}$ of $0.01 \mathrm{M} \mathrm{BeF} 2$ or citrate. The injection sites were excised $2 \mathrm{hr}$ later and the immunological state was checked 15 days later by skin testing with $\mathrm{BeF}_{2}$. Comparisons were made with animals given an injection without excision of the sites of injection. The results (table VII) showed that after excision the degree of sensitisation was reduced in the group given an injection of fluoride $(P=0.05)$ (comparison groups 3,4$)$ when this was compared with the group in which the skin was left intact. With citrate the excision of the injection sites did not modify the immunological response (groups 5,6 ). The conclusion is that the rate of disappearance depends on the chemical form of the injected beryllium.

\section{Discussion}

It has been shown that in guinea-pigs beryllium induces either skin sensitisation or immunological paralysis (tolerance). The state of tolerance is recognised 
by inhibition of the specific delayed skin hypersensitivity reactions elicited by topical application of the hapten, i.e., beryllium. The factors that may be involved are summarised in fig. 3.

A specific delayed hypersensitivity results only from the contact of beryllium with skin; parenteral injection fails to sensitise or may induce an immunological tolerance. The particular role of the skin seems to depend upon the combination of beryllium with one of its constituents, leading to an allergenic depot with subsequent slow release of antigenic material. The difference observed in the sensitising effect of fluoride and sulphate applied percutaneously (table I) may depend on their diffusion properties, which enable them to pass through the skin; indeed, injected intradermally both bind to the skin to the same extent (table V) and have the same immunological action (table VII). Beryllium reacts strongly both in vitro and in vivo with serum proteins (Aldridge, Barnes and Denz, 1949; Belman, 1957; Vacher and Stoner, 1968a), and in vivo beryllium can react with the skin (Belman, 1969). Beryllium also inhibits some enzymes (Thomas and Aldridge, 1966) and might also react with cell membranes (as suggested by Belman, 1969). The percutaneous application of beryllium gives rise to non-specific skin reactions, and after ID injection most of it becomes fixed to the tissues and escapes slowly from the injection site (table V). In rabbits, beryllium has been shown to remain in situ after subcutaneous injection for as long as $3 \mathrm{mth}$ (Aldridge $e t$ al.). The differences in the reactivity of guinea-pigs from different breeders to beryllium have a genetic basis (Polák et al., 1968). Whether or not this is due to a lack in some animals of a specific protein to act as carrier in the antigenic combination with beryllium, or to differences in the lymphocyte population is not known. The role of the combination of beryllium with skin constituents in the induction of contact sensitisation is further demonstrated by the experiments on the excision of the intradermal injection sites. The excision of the allergenic depots of beryllium (as $\mathrm{BeF}_{2}$ ) $2 \mathrm{hr}$ after injection, is followed by a partial immune paralysis (table VII), presumably due to a diffusible form of beryllium escaping very rapidly from the injection site (table V).

Therefore, it seems likely that the sensitisation elicited either by ID injection or percutaneous application is the resultant of concomitant immunisation (by skin-bound beryllium) and tolerance (by diffusible beryllium). The same conclusion has been drawn from recent experiments on the immune paralysis that develops after the excision of allergenic depots of other haptens injected ID (DNCB-picrylchloride, Macher and Chase, 1969a) or applied percutaneously (DNCB, Lowney, 1965).

It was noticed that the diffusible fraction of beryllium increased with the molarity of the solutions injected (fig. 3). An increase of this fraction, as for instance with citrate (Van Cleave and Kaylor, 1953), could explain why the sensitisation obtained by intradermal injection of high doses of beryllium was less than that after smaller doses (Alekseeva, 1966) or why the degree of sensitisation after intradermal injection was lower than after topical application (Belman, 1957). These results support the concept of an interaction between allergen and a skin constituent as being essential for the transformation of the 
simple chemical into the sensitising antigen. Moreover, when this interaction does not take place, a state of immune tolerance can be readily induced, as for instance the one described above after excision of the allergenic depots or even more after intravenous injection (Macher and Chase, 1969b) or feeding (Chase, 1946).

A central failure, i.e., at the level of the lymphocytes, has been shown (by adoptive immunisation by cell transfer) in work on tolerance to allergens induced by feeding (Battisto and Chase, 1955, 1963). The hypothesis that direct access of antigen to lymphoid tissue induces tolerance, whereas indirect access via macrophages induces immunity, would explain the present results. However, one must bear in mind that tolerance has been elicited with a simple hapten. According to this hypothesis, the immune paralysis observed after the IP injection of beryllium (table II) should result from the direct contact of beryllium with the lymphoid system. This is supported by the observation that the tolerogenic action of beryllium is suppressed by its incorporation in complete Freund adjuvant or by its injection in animals pre-treated with glycogen, which is known to stimulate a macrophage proliferation (table IV). The suppression of the tolerogenic action is due to the phagocytosis of the beryllium particles, which cannot now reach the lymphocytes. The protective effect of phagocytosis is also suggested when stimulation of the RE system was produced incidentally by infection following excision of the injection sites (table VII). In this experiment the possibility of a binding between skin constituents and circulating beryllium with the subsequent formation of an antigenic material is probable, because the hapten cannot by itself induce an immunisation even after phagocytosis.

These results suggest that after administration beryllium is taken up by various organs, the uptake depending on its physical (particle size) and chemical form. These events can lead to different immunological situations.

Beryllium can be bound to proteins to form an antigenic material. As far as the delayed type of hypersensitivity is concerned, this antigenic complex can be formed only with skin proteins. Some protein binding will occur after IV injection (Vacher and Stoner, 1968a) and probably after IP injection these complexes of beryllium do not induce hypersensitivity; no humoral form of immunity (in terms of antibodies) has been found (unpublished results) by the use of Farr's method (Farr, 1958), though this, of course, cannot be regarded as proved.

Beryllium can also be, in part, freely diffusible. After IV injection of $\mathrm{BeSO}_{4}$ in rats, this small-particle-size form has been shown to be phagocytosed much more slowly than the big aggregates that are also formed (Vacher and Stoner, 1968b); the diffusibility of the salt has been thought to be determined by the associated organic acid, such as citrate (Feldman, Havill and Neuman, 1953). This is confirmed in our experiment on elimination from skin, in which it has been shown that the diffusible part is much more evident after the ID injection of the citrate than of the fluoride or sulphate. This diffusible fraction was associated with the tolerogenic action, which could be explained by a direct interaction of the hapten with the virgin lymphoid cells. As soon as the process of sensitisation is induced by the antigenic material resulting from the interaction of beryllium with a 
specific skin protein, tolerogenic activity can be elicited only by large toxic doses.

The final immune response, therefore, depends on the relative proportions of these fractions of beryllium, which vary according to the route of administration.

Some other factors must also be involved, such as a difference in the distribution and the rate of elimination of beryllium. It is indeed surprising not to induce the same degree of immune paralysis by pre-treatment with IV injection as with IP, and not to demonstrate tolerance after excision of injection sites after ID injection of the citrate. This could possibly be explained by rapid excretion of the diffusible, tolerogenic, fraction of beryllium. The role of slow release from the deposition sites in organs in the maintenance of the tolerance initiated by IP injection has also to be considered.

For the reasons discussed, it is difficult to calculate the actual amount of beryllium responsible for the production of immune paralysis. However, two dose ranges have been described; one very low, since as little as $5 \mu \mathrm{g}$ Be per kg IP induces a partial paralysis, which becomes almost complete 56 days after $38.3 \mu \mathrm{g}$ (table II); the other very high, as when toxic doses of $\mathrm{BeSO}_{4}$ (this paper) or beryllium lactate (Polák and Turk, 1968) are injected IV. This seems to fit the model described by Mitchison $(1964,1968)$ for the tolerance induced in adult animals with a protein antigen. In this study, it was not possible to demonstrate the intermediate zone of immunisation since beryllium is administered in a non-antigenic form, and the intimate mechanism of the immune paralysis remains unknown. It could perhaps be linked with the adjuvant property of beryllium recently described (Unanue, Askonas and Allison, 1969), and possibly explained by a cell division of the immunologically competent cells, which would then become insensitive to a further antigenic stimulus.

\section{SUMMARY}

In adult guinea-pigs, beryllium induces either a skin sensitisation or an immunological paralysis.

Skin delayed hypersensitivity results only from the contact of beryllium with the skin. Parenteral administration fails to sensitise, but may induce tolerance. These immune responses are associated with different forms of beryllium: immunogenic (bound to skin constituents) and tolerogenic (freely diffusible). The relative proportion of these fractions depends on the route of administration and on the salt of beryllium. The tolerant state is achieved either by intraperitoneal injection of a very low dose of beryllium $(4.78 \mu \mathrm{g} \mathrm{Be} \mathrm{per} \mathrm{kg}$ intraperitoneally) or by intravenous injection of high toxic doses (400 $\mu \mathrm{g} \mathrm{Be} \mathrm{per} \mathrm{kg}$ ); this fits with the model described by Mitchison (1968) for protein antigens.

I wish to thank Dr I. Sutherland for advice on the treatment of the results and Dr A. L. Johnson for carrying out the statistical analysis. Mr C. R. Kennedy and Mrs N. Marks gave skilled assistance with the animals.

\section{REFERENCES}

Aldridge, W. N., Barnes, J. M., AND Denz, F. A. 1949. Experimental beryllium poisoning. Br. J. Exp. Path., 30, 375. 
Alekseeva, O. G. 1966. Ability of beryllium compounds to cause allergy of the delayed type. Fedn Proc., 25, T843.

Battisto, J. R., AND Chase, M. W. 1955. Immunological paralysis in guinea pigs fed allergenic chemicals. Fedn Proc., 14, 456.

BATtisto, J. R., AND ChaSe, M. W. 1963. Immunological unresponsiveness to sensitization with simple chemical compounds. A search for antibody-absorbing depots of allergen. J. Exp. Med., 118, 1021.

Belman, S. 1957. Beryllium binding of bovine serum albumin and epidermal constituents. Ph.D. Thesis, New York Univ.

Belman, S. 1969. Beryllium binding of epidermal constituents. J. Occup. Med., 11, 175.

Chase, M. W. 1946. Inhibition of experimental drug allergy by prior feeding of the sensitizing agent. Proc. Soc. Exp. Biol. Med., 61, 257.

Chiappino, G.. Barbiano di Belgiojoso, G., and Cirla, A. M. 1968. La ipersensibilità ai composti di berillio; inibizione mediante siero anti-linofocitario della intradermoreazione nella cavia. Boll. Ist. sieroter. milan., 47, 669.

Chiappino, G., Cirla, A., and Viglian, E. C. 1969. Delayed-type hypersensitivity reactions to beryllium compounds. An experimental study. Archs Path., 87, 131.

Cirla, A. M., Barbiano di Belgiojoso, G., AND Chiappino, G. 1968. La ipersensibilità ai composti di berillio: transferimento passivo nella cavia mediante cellule linfoidi. Boll. Ist. sieroter. milan., 47, 663.

CurTIs, G. H. 1951. Cutaneous hypersensitivity due to beryllium; study of 13 cases. Archs Derm. Syph., 64, 470.

DeNardi, J. M., Van Ordstrand, H. S., AND Carmody, M. G. 1949. Acute dermatitis and pneumonitis in beryllium workers: review of 406 cases in an 8-year period with follow-up on recoveries. Ohio St. Med. J., 45, 567.

DunCAN, D. B. 1955. Multiple range and multiple F tests. Biometrics, 11, 1.

Dutra, F. R. 1951. Experimental beryllium granulomas of the skin. Archs Indust. Hyg., 3,81 .

FARR, R. S. 1958. A quantitative immunochemical measure of the primary interaction between I*BSA and antibody. J. Infect. Dis., 103, 239.

Feldman, I., Havill, Jean R., and Neuman, W. F. 1953. The state of beryllium in blood plasma. Archs Biochem. Biophys., 46, 443.

LowNEY, E. D. 1965. Immunologic unresponsiveness appearing after topical application of contact sensitizers to the guinea pig. J. Immun, 95, 397.

McCord, C. P. 1951. Beryllium as a sensitizing agent. Industr. Med. Surg., 20, 336.

MACHER, E., AND CHASE, M. W. 1969a. Studies on the sensitization of animals with simple chemical compounds. XI. The fate of labeled picryl chloride and dinitrochlorobenzene after sensitizing injections. J. Exp. Med., 129, 81.

MACHER, E., AND CHASE, M. W. 1969b. Studies on the sensitization of animals with simple chemical compounds. XII. The influence of excision of allergenic depots on onset of delayed hypersensitivity and tolerance. J. Exp. Med., 129, 103.

Mitchison, N. A. 1964. Induction of immunological paralysis in two zones of dosage. Proc. Roy. Soc. B, 161, 275.

Mitchison, N. A. 1968. The dosage requirements for immunological paralysis by soluble proteins. Immunology, 15, 509.

PolÁk, L., Barnes, J. M., AND TuRK, J. L. 1968. Genetic control of contact sensitization to inorganic metal compounds in guinea-pigs. Immunology, 14, 707.

Polák, L., AND TURK, J. L. 1968. Studies on the effect of systemic administration of sensitizers in guinea-pigs with contact sensitivity to inorganic metal compounds I. The induction of immunological unresponsiveness in already sensitized animals. Clin. Exp. Immun., 3, 245.

Short, D. J., and Gammage, L. 1959. A new pelleted diet for rabbits and guinea pigs. J. Anim. Techns Assoc., 9, 62.

STERnER, J. H., AND EISENBUd, M. 1951. Epidemiology of beryllium intoxication. Archs Indust. Hyg., 4, 123. 
Thomas, Molly, and Aldridge, W. N. 1966. The inhibition of enzymes by beryllium. Biochem. J., 98, 94.

Unanue, E. R., Askonas, Brigitte A., And Allison, A. C. 1969. A role of macrophages in the stimulation of immune responses by adjuvants. J. Immun., 103, 71 .

VACHER, J., AND STONER, H. B. 1968a. The transport of beryllium in rat blood. Biochem. Pharmac., 17, 93.

VACHER, J., AND STONER, H. B. 1968b. The removal of injected beryllium from the blood of the rat. The role of the reticuloendothelial system. Br. J. Exp. Path., 49, 315.

Van Cleave, C. D., and Kaylor, C. T. 1953. Distribution and retention of carrier-free radioberyllium in the rat. Archs Indust. Hyg., 7, 367.

Weber, H. H., AND ENGELHARDT, W. E. 1933. UUber eine Apparatur zur Erzeugung niedriger Staubkonzentrationen von grosser Konstanz und eine Methode zur mikrogravimetrischen Staubbestimmung. Anwendung bei Untersuchung von Stauben aus der Berylliumgewinnung. Zentbl. Gewerbehyg. Unfullverhüt., 10, 41. 